\title{
Kuinka tukea terveydenhuollon ammattilaisia, jotka ovat turvapaikanhakijoina tai pakolaisina Suomessa?
}

\author{
NOORA BERG, THAIR AL-JANABI, PÄIVI SANTALAHTI
}

Kesällä ja syksyllä 2015 Suomeen saapui ennätysmäärä turvapaikanhakijoita pääosin Irakista, Afganistanista, Somaliasta ja Syyriasta (1). Turvapaikanhakijoiden tuloa kuvattiin luonnonilmiönä muun muassa tulvana ja aaltona, mutta turvapaikanhakijat ovat isiä ja äitejä, jonkun lapsia, siskoja ja veljiä. Turvapaikanhakijat eivät kaikki ole aallon samankaltaisia pisaroita, vaan joku on insinööri, joku lääkäri tai sairaanhoitaja, taiteilija, journalisti, juristi, leipuri, maanviljelijä, kaupanpitäjä, taksikuski, opettaja tai psykologi. Sandbergin ja Stordellin (2) selvityksen mukaan 27 prosentilla turvapaikanhakijoista oli akateemista koulutusta. Viranomaiset, ammattilaiset ja tuhannet vapaaehtoiset tarttuivat toimeen Suomessa uudessa tilanteessa. Kuvaamme tässä prosessia, jonka perusidea oli kohdata vastaanottokeskuksissa asuvia terveydenhuoltoalan ammattilaisia ammatillisesti.

Aikaisemmat tutkimukset ovat todenneet EU ja ETA alueiden ulkopuolelta tulevien terveydenhuollon ammattilaisten integroitumisen esteiksi opastuksen puutteen laillistamisprosessissa, ongelmat kielitaidoissa ja vakiintuneiden valmentavien kurssien puutteen. Lisäksi harjoittelupaikkojen saaminen on hankalaa ja eri viranomaisten, terveydenhuollon ja ammatillisten järjestöjen yhteistyön koordinoinnissa on puutteita. (3-7) Kun tulija on turvapaikanhakija, on hän psykologisesti ja konkreettisesti hämmentävässä ja vaikeassa tilanteessa asuessaan useimmiten vastaanottokeskuksen laitosmaisissa olosuhteissa kantaen huolta läheisistään tulevaisuuden ollessa epävarma.

Terveyden ja hyvinvoinnin laitoksella järjestettiin yhteistyössä Työ- ja elinkeinoministeriön kanssa joulukuusta 2015 syksyyn 2016 kestänyt hanke, jonka tavoitteena oli tukea turvapaikanhakijoina tai pakolaisina Suomessa olevia terveydenhuollon ammattilaisia (8). Hanketyöryhmään kuului yksi itse turvapaikanhakijana oleva lääkäri. Hankkeen aikana tehtiin kirjallisuuskatsaus ja selvitettiin muiden maiden käytäntöjä EU ja ETA alueiden ulkopuolelta tulleiden terveydenhuollon ammattilaisten integraatioon liittyen. Kohderyhmälle järjestettiin myös ammatillinen seminaarisarja, jossa kerrottiin muun muassa väestön terveydestä, Suomen tyypillisimmistä terveysongelmista, lisääntymisterveydestä, perusterveydenhuollosta, äitiys- ja lastenneuvoloista ja Käypä hoito - suositusten periaatteista. Lisäksi seminaareissa esiteltiin lääkärien ja sairaanhoitajien ammattijärjestöjä, terveydenhuollon laillistamisprosessia ja mahdollisuuksia ammatilliseen kielikoulutukseen. Mielenterveys oli yksi seminaarin keskeisistä teemoista, koska usein maissa, joista seminaarien osallistujat tulivat, mielenterveyspalveluilla ei ole vastaavaa roolia kuin suomalaisessa järjestelmässä. Lisäksi seminaareissa ja vastaanottokeskuksissa oli mahdollista osallistua kyselyyn, jossa kartoitettiin Suomessa olevien terveydenhuollon ammattilaisten määrää, koulutusta, työkokemusta ja kielitaitoa.

Kyselyyn vastasi kaikkiaan 62 henkilöä, joista 71 prosenttia oli turvapaikanhakijoita ja 29 prosenttia pakolaisia. Kyselyn tuloksia on pidettävä suuntaa antavina, eikä katoa tai vastaajajoukon edustavuutta ole mahdollista arvioida luotettavasti, koska ei ole olemassa tarkkaa tietoa kohdejoukon koosta. Suurin osa kyselyyn vastanneista oli lääkäreitä (44\%) ja heistä noin kolmasosa oli erikoislääkäreitä. Vastanneissa oli lääkäreiden lisäksi myös hammaslääkäreitä 
(19\%), sairaanhoitajia (18\%), farmaseutteja (8\%), laboratoriohenkilökuntaa (5\%) sekä muita ammattiryhmiä kuten kätilöitä, psykologeja ja opiskelijoita (7\%). Suurin osa vastaajista oli miehiä ja iältään nuorimmat olivat 21-vuotiaita ja vanhimmat yli 50 . Suurin osa $(75 \%)$ oli iältään alle 34 vuotta ja valmistunut vuonna 2008 tai sen jälkeen. Muut olivat valmistuneet 2000-2007. Neljäsosalla (24\%) ei ollut ammattitodistusta mukanaan, tosin lääkäreistä näin oli vain neljällä prosentilla vastaajista. Suurin osa $(80 \%)$ oli suorittanut tutkintonsa lähtömaassaan, 11 prosenttia Ukrainassa ja loput 9 prosenttia muualla. Suurin osa vastaajista puhui arabiaa $(85 \%)$ ja lähes kaikki raportoivat puhuvansa englantia vähintään jonkin verran (94\%). Tämän lisäksi 18 prosenttia raportoi osaavansa venäjää ja 26 prosenttia jotain muuta kuin edellä mainittua kieltä. Yli puolet vastaajista asui Helsinki-Uusimaa alueella (53\%), 24 prosenttia muualla Etelä-Suomessa, 14 prosenttia Länsi-Suomessa ja 10 prosenttia Pohjois- ja Itä-Suomen alueella. (8)

Seminaareihin osallistui monipuolisesti eri terveydenhuollon ammattiryhmiä ja niihin olivat tervetulleet myös muut kuin turvapaikanhakijat ja pakolaiset. Seminaarit edistivät vuoropuhelua pakolaisten, turvapaikanhakijoiden ja suomalaisten ammattilaisten välillä. Vaikka tärkeää oli välittää tietoa suomalaisesta terveydenhuollosta vasta maahan tulleille, yhtä tärkeää oli myös lisätä suomalaisten toimijoiden ymmärrystä maahantulijoista. Hanke aloitettiin ja toteutettiin nopealla aikataululla. Tämä oli mahdollista monien eri tahojen ollessa valmiita auttamaan lyhyellä varoitusajalla. Ennennäkemättömän suuri määrä turvapaikanhakijoita Suomessa oli poikkeuksellinen tilanne, joka näyttää aktivoineen eri toimijoissa joustavuutta ja yhteistyötä, mikä niin sanotuissa normaalioloissa ei aina tule esiin. Suomen Lääkäriliitto osallistui kahteen seminaariin ja teki kaksi artikkelia turvapaikanhakijalääkäristä Suomen Lääkärilehteen (9-10). Nyt liitto on aloittamassa mentorointijärjestelmää turvapaikanhakija- ja pakolaislääkäreiden tueksi.

Hankkeen aikana havaittiin samantyyppisiä maahantulijoiden integroitumiseen liittyviä vaikeuksia kuin aikaisemmatkin tutkimukset olivat raportoineet. Laillistamisprosessista on vaikea saada kokonaiskuvaa ja tieto on hajanais- ta. Lisäksi samassa tilanteessa olevien verkostoituminen oli osin hankalaa, koska Suomessa turvapaikanhakijoina olevat terveydenhuollon ammattilaiset on sijoitettu eri puolille Suomea, monet syrjäisille seuduille hankalien kulkuyhteyksien päähän. Tällöin esimerkiksi koulutustilaisuuksiin osallistuminen, opintopiirien järjestäminen ja muiden kohtaaminen vaikeutuvat. Erilaiset Facebook-ryhmät kuten Refugee doctors in Finland ja Lääkäriksi Suomeen -ryhmät ovat pyrkineet paikkaamaan tiedonkulun vajeita, vaikka ne eivät pystykään vastaamaan kasvotusten tapahtuvan tiedonvälityksen tarpeeseen. Laillistamisprosessin aloittamisessa ja sen edetessä tarvitaan yksityiskohtaista tietoa siitä, missä järjestyksessä prosessi etenee, miten harjoittelupaikka hankitaan, miten terveyskeskukset ja sairaalat löydetään ja kehen ja millä tavoin ottaa yhteyttä.

Kun terveydenhuollon ammattilainen saapuu Suomeen, olisi hänen tärkeää mahdollisimman nopeasti saada kattava käsitys koko edessä olevasta laillistamisprosessista. Monille ammatinharjoittaminen on ollut tärkeä osa minäkuvaa. Jos tarvittavat vaiheet saavuttaa tuo päämäärä uudelleen ovat selvät, näyttäytyy tulevaisuus toiveikkaalta ja jäsennellyltä, vaikka prosessi itsessään olisikin vaikea ja pitkä. Tämän kattavan kuvan saamista voidaan edistää ainakin kahdella tavalla. Selkeiden, helposti lähestyttävien internetsivujen merkitys on etenkin prosessin ensivaiheissa tärkeä. Keskitetysti internetistä saatava kattava tieto todennäköisesti vähentäisi suoria yhteydenottoja viranomaisiin ja säästäisi myös heidän aikaansa. Myös lyhyt nopeasti maahan saapumisen jälkeen järjestettävä kurssi, jossa esiteltäisiin laillistamisprosessi, tietolähteet, kielikurssit ja suomalaisen terveydenhuollon peruspiirteet, olisi hyödyllinen edessä olevaa laillistamisprosessia ajatellen. Erityisesti tarvitaan tietoa siitä, miten eri ammatillisissa vaiheissa olevien tulisi edetä (esim. lääketieteen opiskelija vs. erikoislääkäri).

Viranomaisten ja muiden erilaisten toimijoiden lisäksi tärkeä tiedonvälityksen kanava ovat muut jo pidempään maassa olleet turvapaikanhakijat ja pakolaiset. Olisi hyödyllistä keskittää terveydenhuollon turvapaikanhakijoiden asuminen lähelle toisiaan, mahdollisesti alueelle, jossa on yliopistollinen sairaala. Näin turvapaikan- 
hakijoilla on mahdollisuus vertaistukeen, tiedonjakamiseen ja osallistuminen jo olemassa oleville kursseille ja seminaareihin olisi helpompaa.

Prosessin aikana oli, sekä seminaarien sisältöjen että käytännön järjestelyiden kannalta, merkityksellistä, että hankkeen työryhmässä oli mukana henkilö, joka itse edusti kohderyhmää. Tämä on asia, johon tulisi jatkossa kiinnittää enemmän huomiota niin erilaisia hankkeita kuin tutkimuksiakin suunniteltaessa.

Tiukat vaatimukset EU ja ETA alueiden ulkopuolelta tulevien terveydenhuoltoammattilaisten pääsyssä suomalaiseen työelämään ovat perusteltuja - ei vähiten potilasturvallisuuden takaamiseksi. Sitä, kuinka integroituminen etenee, voidaan kuitenkin kehittää sujuvammaksi, jotta tulijat pystyisivät käyttämään kapasiteettiaan heti Suomeen tullessaan mahdollisimman hyvin. On hyödyllistä, että suomalaiset ammattilaiset tutustuvat henkilökohtaisesti ammattilaisiin, jotka tulevat maista, joista meille saapuu turvapaikanhakijoita ja pakolaisia. Yhdessä tekemällä kaikki hyötyvät.

\section{LÄHTEET}

(1) Maahanmuuttovirasto. Asylum applicants 1.1.-31.12.2015. Luettu 1.3.2017. http://www. migri.fi/download/65010_EN_tp-hakijat_2015. pdf

(2) Sandberg T, Strodell E. Vastaanottokeskuksissa toteutettu alkuvaiheen osaamisen tunnistaminen. Testipiste. 2016. Luettu 20.6.2017. http:// minedu.fi/documents/1410845/4240776/VOKraportti_2016/86ea0123-d929-4aa6-b45395eaa1ec2dd7

(3) Kuusio H. A comparative study on challenges in the psychosocial work environment of Finnish and foreign-born general practitioners. Academic Dissertation. National Institute for Health and Welfare and Hjelt Institute of Public Health, Faculty of Medicine, Helsinki, Finland. Helsinki: National Institute for Health and Welfare. Research 121;2014. Luettu 20.6.2017. https://helda.helsinki.fi/bitstream/ handle/10138/42613/kuusio_dissertation. pdf? sequence $=1$

(4) Haukilahti R-L. ETA-alueen ulkopuolella tutkintonsa suorittaneet lääkärit Suomessa. Tampere: Acta Universitatis Tamperensis. Tampere University Press; 2014.

(7) Muskoe S. Foreign doctors and the road to a Swedish Medical License. Experienced barriers of doctors from non-EU countries. Södertörn University, School of Life Science; 2012.

(8) Santalahti P, Al-Janabi T, Berg N. Supporting health care professionals who are asylum seekers or refugees in starting their licensing process in Finland. Helsinki: National Institute for Health and Welfare 41/2016.

(9) Vierula H. Matka tuntemattomaan. Suomen lääkärilehti 2016; 71: 862-864.

(10) Vierula H. Uuden elämän alussa. Suomen lääkärilehti 2016; 71: 3069.

NoOra Berg

FT, tutkija

Terveyden ja byvinvoinnin laitos, Mielenterveysyksikkö

Uppsalan yliopisto, Institutionen för folkhälsooch vardvetenskap

Thair Al-Janabi

$M D$

(5) Markkanen S. Integration or Discrimination: Opportunities and Barriers to Appropriate Paid Employment for Healthcare Professional Refugees in Finland. Web Reports 40. Institute of Migration; 2008. Luettu 20.6.2019. http:// www.migrationinstitute.fi/files/pdf/webreport/ webreport_040.pdf

(6) Lämsä R, Manderbacka K, Kuusio H, Aalto A-M, Elovainio M. Ylilääkärien ja ulkomaalaistaustaisten lääkärien kokemuksia toimilupaprosessista. Suomen lääkärilehti 2012; 37: 2555-2560.

\section{PäIVI Santalahti}

LT, ylilääkäri

Terveyden ja hyvinvoinnin laitos, Mielenterveysyksikkö 